\title{
Role of nitric oxide during neurogenesis in the olfactory epithelium
}

\author{
LORENA SULZ and JUAN BACIGALUPO
}

Departamento de Biología, Facultad de Ciencias, Instituto de Dinámica Celular y Biotecnología, Universidad de Chile

\begin{abstract}
In mammals, neurogenesis continues during adulthood in restricted places of the nervous system, namely the subventricular zone, the dentate gyrus and the olfactory epithelium. A dual role of the second messenger nitric oxide has been reported in such places, either promoting or inhibiting proliferation of neuronal precursors depending on the cellular signal implicated. In this review the regulation of adult olfactory epithelium neurogenesis by nitric oxide is discussed.
\end{abstract}

\section{INTRODUCTION}

This review discusses recent cellular and molecular studies on the effects of the second messenger nitric oxide (NO) on neurogenesis in the adult olfactory epithelium, the tissue comprising the sensory cells of the sense of smell. In the olfactory epithelium, neurogenesis occurs throughout adult life, allowing the replacement of dying olfactory sensory neurons. Nitric oxide seems to act as a proliferative agent of neuronal precursors in the olfactory epithelium. The mechanism involved in this complex regulation is discussed.

\section{Neurogenesis and the adult neuronal regeneration}

Neurogenesis is the process by which new neurons are generated from precursor cells. This process involves the proliferation, migration and differentiation of neuronal precursors from stem cells to mature neurons. It was believed for over 50 years that in mammals neurogenesis occurred exclusively within a limited time period during embryonic development. However, the generation of new neurons in a few areas of the adult nervous system has been recently demonstrated.

Adult neurogenesis was described for the first time in rat hippocampus (Altman and Das, 1965) and, more recently, in the primate dentate gyrus (Gould et al., 1997; Eriksson et al., 1998). It has been proposed that adult neurogenesis is accompanied either by an increase in the neuronal number (Boss et al., 1985) or the replacement of dying neurons (Gould and Tanapat, 1999).

The ability to generate new neurons in adulthood distinguishes the hippocampus, the olfactory bulb and the olfactory epithelium from the rest of the nervous system. The generation of new granular cells in the dentate gyrus has been reported, as well as the fact that new neurons are generated in the subventricular zone. These neurons migrate to the olfactory bulb, where they differentiate into mature interneurons and glomerular cells (Graziadei, 1973; Moulton, 1974; Graziadei and Monti Graziadei, 1980).

As in other regenerating tissues, such as the skin, liver and hematopoietic cells, the presence of stem cells that give origin to the differentiated cells has been reported in the olfactory epithelium. 


\section{Olfactory epithelium}

The olfactory epithelium contains three different cell types: supporting cells, sensory neurons and basal cells (Fig 1). The basal cells can be classified in horizontal cells, which express cytokeratin and exhibit a flat shape, and global cells, which have spherical shape and do not express cytokeratin. The olfactory epithelium is divided in three layers: basal, apical and intermediate. The apical layer contains the somata of the supporting cells (Hempstead and Morgan, 1983), the basal layer is adjacent to the basal membrane and contains the horizontal basal cells (Graziadei and Monti Graziadei, 1980; Calof and Chikaraishi, 1989) and in the intermediate layer are located the somata of the sensory neurons. These neurons display a bipolar shape, bearing a soma with an axon on one end and a single dendrite on the other. The dendrite terminates in the dendritic knob, the structure from where the chemosensory cilia project into the nasal cavity (Schild and Restrepo, 1998).

Olfactory transduction begins when the odorants bind to their receptors, located in the chemosensory cilia (Rhein and Cagan,
1980; Menco et al., 1997). These receptors are proteins belonging to the $G$ proteincoupled receptor family, with seven transmembrane domains (Buck and Axel, 1991). When the receptors are activated upon odorant binding, they stimulate type III adenylyl cyclase (ACIII) (Bakalyar and Reed, 1990) through a G-protein termed $G_{\text {olf }}$ (Jones and Reed, 1989). cAMP generated by this cyclase directly activates a non-specific cationic channel, known as cyclic nucleotide gated channel (CNGC) (Firestein et al., 1991; Scott et al., 1996). The opening of CNGC leads to an increase in free $\mathrm{Ca}^{2+}$ levels inside the cilia (Goulding et al., 1992), activating either a $\mathrm{Cl}^{-}$or a $\mathrm{K}^{+}$channel, eliciting an excitatory or an inhibitory response, respectively (Morales et al., 1994; Morales and Bacigalupo, 1996; Morales et al., 1997).

\section{The stem cells of the olfactory epithelium}

The term stem cells refers to immortal, multipotential cells with asymmetric division that can give origin to several cell types in a given tissue. Instead, precursor cells are those cells committed to a particular cellular fate (Cameron and McKay, 1998).

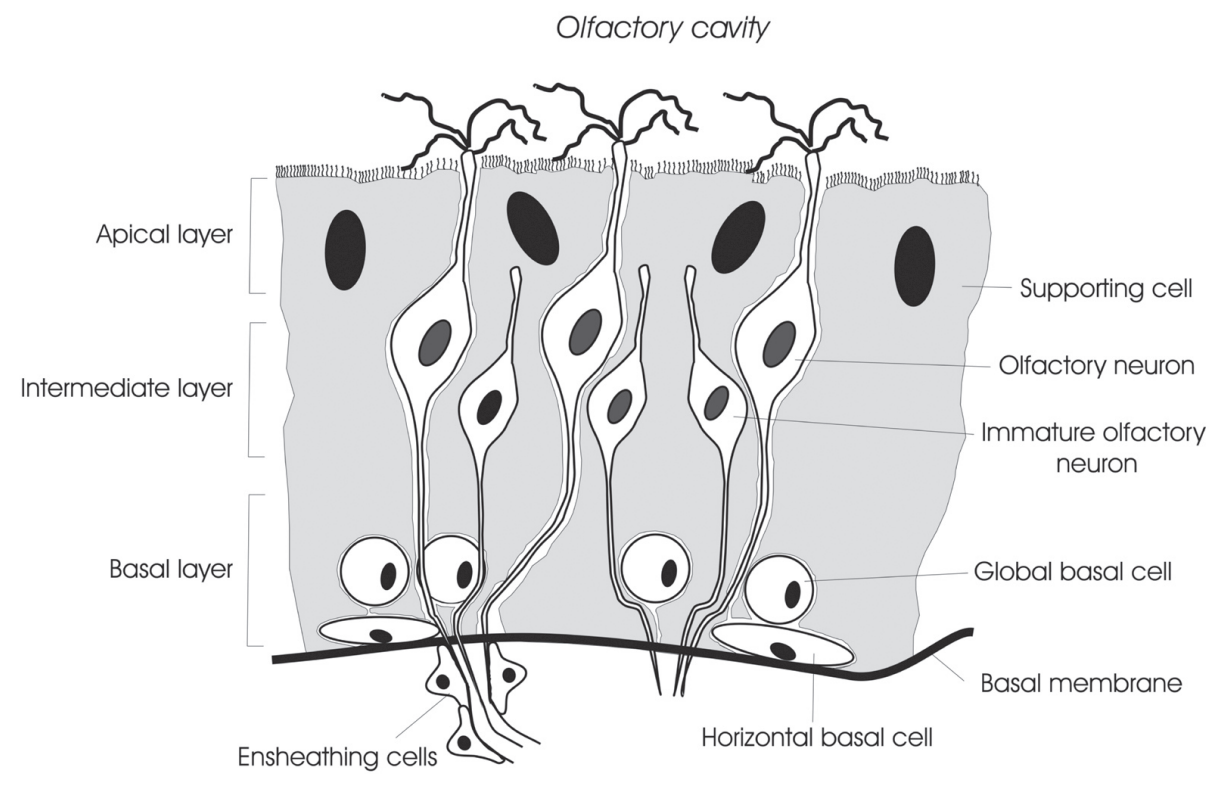

Lamina propria

Figure 1: Olfactory epithelium displaying its different cell types in their characteristic spatial distribution in the tissue. 
Early radiographic studies suggested that the olfactory stem cells are part of the basal cells (Graziadei, 1973; Harding et al., 1977). Now it is generally accepted that new neurons and supporting cells arise from proliferation and differentiation of basal cells, although the cellular identity of the stem cells is still under debate, mostly because of the unavailability of specific markers for quiescent and undifferentiated cells such as the stem cells from adult tissues (Weiss and van der Kooy, 1998; Gage, 2000). There is evidence supporting both, horizontal and global basal cells as the olfactory epithelium stem cell. It has been proposed that the stem cells represent a subpopulation of the global basal cells, because they are mitogenic and multipotential (Caggiano et al., 1994; Feron et al., 1999a). Furthermore, at the peak of neurogenesis in the regenerating olfactory epithelium, most of the mitotic cells are global basal cells, rather than horizontal basal cells (Carter et al., 2004). The idea that horizontal basal cells are stem cells is based on the fact that they are a relatively quiescent cell population. As the stem cells of the hippocampus and subventricular zone, they respond in vitro and in situ to EGF and TGF- $\alpha$ (Farbman and Buchholz, 1996; Getchell et al., 2002). Furthermore, horizontal basal cells are adjacent to the basal membrane and express the same cell adhesion molecules as the stem cells of other non-neuronal systems, such as the colon and the epidermis (Carter et al., 2004), and they give rise to all olfactory epithelium cell types (Leung and Reed, 2006). This evidence suggests that horizontal basal cells correspond to the stem cells, whereas global basal cells are the neuronal precursors.

Basal cell mitosis occurs in two phases, slow and fast, in the same way as in the developing nervous system (Mackay-Sim and Kittel, 1991). During the slow phase, a stem cell divides every 50 days producing another stem cell, which stays close to the basal membrane, and a precursor cell which rapidly divides at least two to three times, generating many immature neurons. These immature neurons migrate away from the basal membrane as they differentiate (Mackay-Sim and Kittel, 1991).
Neuronal regeneration in the olfactory epithelium

\section{In situ studies}

Normally, there is a permanent neuronal production in the olfactory epithelium, where a small fraction of the ORNs die and are replaced by new ones. In rodents, individual olfactory neurons can live for one year or further (Hinds et al., 1984). Neurons may die at anyone of several stages of their life cycle (Farbman, 1990; Carr and Farbman, 1992; Schwob et al., 1992; Mahalik, 1996), some of them as early as one day after mitosis (Carr and Farbman, 1992). Moreover, experimental damage destroying mature ORNs is followed by an almost complete regeneration and functional restoration of the tissue a few weeks after the lesion, depending on the magnitude of the damage (Schultz, 1960; Graziadei and Monti Graziadei, 1983; Astic and Saucier, 2001). When ORNs are damaged, the rate of basal cell mitosis increases dramatically (Camara and Harding, 1984) and the progeny differentiates into fully mature neurons, expressing the olfactory marker protein (OMP) (Graziadei, 1973). Since neurogenesis occurs throughout the life span, it provides the adult olfactory epithelium with the capacity to replace the damaged olfactory sensory neurons, even after an extensive lesion such as that produced by axotomy (Smith, 1951; Schultz, 1960; Westerman and von Baumgarten, 1964; Graziadei and Monti Graziadei, 1979); or by exposure to xenobiotics such as zinc sulphate (Cancalon, 1982), methyl bromide (Hurtt et al., 1988; Schwob et al., 1995), Triton X100 (Verhaagen et al., 1990), dichlobenil (Brandt et al., 1990; Delaleu and Sicard, 1995), copper (Saucier and Astic, 1995), iminodipropionitrile (Genter et al., 1994) or sulphur dioxide (Min et al., 1994). After axotomy, when the olfactory bulb (the synaptic target of ORN) is removed, the olfactory epithelium regenerates only partially, due to the lack of trophic factors (Schwartz Levey et al., 1991; Gordon et al., 1995). In the case of chemical damage (zinc 
sulphate or methyl bromide), however, the olfactory epithelium is fully restored (Cancalon, 1982; Schwob et al., 1995), allowing the experimental manipulation of the regeneration rate.

\section{In vitro studies}

Several primary culture procedures have been developed to obtain olfactory epithelial cells (Cunningham et al., 1999). There are cultures containing only ORNs, which keep their ability to respond to odorants (Barber et al., 2000) and cultures comprising only non-neuronal cells, such as supporting and basal cells (Newman et al., 2000). These cultures can be treated with growth factors that induce the proliferation or differentiation of neuronal precursors. Among the proliferation-promoting growth factors are FGF-2 (Newman et al., 2000), EGF (Mahanthappa and Schwarting, 1993), NGF (Plendl et al., 1999) and LIF (Bauer et al., 2003; Kim et al., 2005). The last one is released by dying ORNs and promotes proliferation of the basal cells (Nan et al., 2001; Getchell et al., 2002). On the other hand, BDNF (Buckland and Cunningham, 1998), NT-3 (Simpson et al., 2003), dopamine (Feron et al., 1999b), IGF-1 (Pixley et al., 1998) and TGF- $\beta 2$ (Mahanthappa and Schwarting, 1993) promote differentiation of neuronal precursors. A key role on regulating neurogenesis during development of the central nervous system has been proposed for these factors. The expression of some growth factors and their receptors continues through the adulthood in the hippocampus, the subventricular zone and the olfactory epithelium (Holbrook et al., 1995; Seroogy et al., 1995; Okano et al., 1996). EGF stimulates proliferation of neuronal precursors in the hippocampus and in the SVZ of adult and new born rats (Tao et al., 1996; Kuhn et al., 1997). Furthermore, the expression of EGF and TGF- $\alpha$ receptors in these three zones of active neurogenesis has been reported (Holbrook et al., 1995; Seroogy et al., 1995; Okano et al., 1996).

The in vitro studies of the olfactory epithelium have allowed the identification several molecular markers, which are used to determine the neuronal differentiation stages. Stem cells express cytokeratin 14 (CK14), intercellular adhesion molecule-1 (ICAM-1) and $\beta 1$-integrin (Satoh and Yoshida, 2000; Carter et al., 2004), while immature neurons express nCAM, (Calof and Chikaraishi, 1989) and initially, specific neuronal tubulin (T $\beta$ III) and GAP43. When fully differentiated, GAP43 disappears and the expression the olfactory marker protein (OMP), gal-nCAM (Pays and Schwarting, 2000) and constituents of the odor transduction pathways, such as ACIII and odorant receptors, can be detected (Illing et al., 2002).

\section{Nitric Oxide and neurogenesis}

Nitric oxide is a gaseous free radical produced by the enzyme nitric oxide synthase (NOS). It participates as a second messenger in intracellular signaling processes in the nervous system (Garthwaite, 1991; Snyder, 1992; Bredt and Snyder, 1994). So far, three NOS isoforms have been described: the inducible isoform (iNOS), whose activity is calcium-independent, the epithelial (eNOS) and the neuronal isoforms (nNOS), both of which depend on calcium. nNOS is expressed by approximately $1 \%$ of the neurons, but not by most adult sensory neurons, such as photoreceptors, olfactory neurons and dorsal root ganglia cells (Dawson et al., 1991; Verge et al., 1992; Schmachtenberg et al., 2001). NO can rapidly reach intra or extracellular targets by diffusion from its production site (Stamler et al., 1997a; Stamler et al., 1997b). The brief half-life and high reactivity of NO severely limit its action range (Garthwaite and Boulton, 1995). Several signaling systems are modulated by NO, whose effects in a given cell depend on the affected pathway. The most common target of $\mathrm{NO}$ is the soluble guanylyl cyclase (sGC) (Van Wagenen and Rehder, 2001). sGC generates the second messenger cyclic GMP (cGMP) upon NO activation. cGMP may gate ion channels and regulate protein kinases (Haynes et al., 1986; Bacigalupo et al., 1991; Pineda et al., 1996; Firestein and Bredt, 1998; Gudi et al., 1999). NO can also modify proteins directly by nitrosylation 
(Stamler, 1994). Protein nitrosilation seems to be involved in regulatory mechanisms of several cellular processes, including signal transduction, DNA repair, blood pressure regulation and neurotransmission (Stamler, 1994; Stamler et al., 1997a).

Different functions have been established for NO in the nervous system of adult animals, such as its participation in the NMDA-induced neurotoxicity (Dawson et al., 1991; Dawson et al., 1993), neuroprotection and neurotoxicity after cerebral ischemia (Moro et al., 2004), GC regulation (Moncada et al., 1991; Nathan, 1992), synaptic plasticity modulation (Edelman and Gally, 1992; Zorumski and Izumi, 1993), neurotrasmissor secretion (Dawson et al., 1994) and neuronal activitydependent gene expression (Peunova and Enikolopov, 1993).

Substantial experimental evidence supports the participation of $\mathrm{NO}$ in neurogenesis, but its specific role remains unclear. The first evidence was morphological, and demonstrated that NOS expression occurs "at the right place in the right moment" during embryonic and adult neurogenesis. It has been reported that NOS expression increases in several neuronal structures during embryonic development, and decreases in adulthood (Bredt and Snyder, 1994; Roskams et al., 1994; Keilhoff et al., 1996; Santacana et al., 1998; Schmachtenberg et al., 2001; Holmqvist et al., 2004). For instance, nNOS expression in the cortical neural plate of the mouse embryo during the period of maximal neurogenesis has been described (Bredt and Snyder, 1994). In the developing zebra fish embryo, the nNOS expression pattern correlates with the patterns of neuronal differentiation (Holmqvist et al., 2004).

During neurogenesis of the adult olfactory system, the expression of nNOS has been reported in both the olfactory bulb and the olfactory epithelium (Roskams et al., 1994). This enzyme is also expressed in the adult mouse SVZ, where the neuronal precursors of the olfactory bulb are generated. Furthermore, after adult mice bulbectomy, NOS is quickly and transiently expressed in the regenerating olfactory neurons (Roskams et al., 1994).
More recent functional studies report opposite effects of NO upon neurogenesis, promoting or inhibiting the proliferation of neuronal precursors (Peunova and Enikolopov, 1995; Kuzin et al., 1996; Obregon et al., 1997; Mize and Lo, 2000). Antiproliferative effects of NO during neurogenesis have been reported in Drosophila during neuronal development, where NO inhibits proliferation through the retinoblastoma $(\mathrm{Rb})$ pathway (Kuzin et al., 1996; Kuzin et al., 2000), during brain development in Xenopus (Peunova et al., 2001) and, in mammals, during brain development (Chen et al., 2003) and in the adult dentate gyrus and SVZ (Packer et al., 2003; Matarredona et al., 2004; MorenoLopez et al., 2004).

On the other hand, NO has been proposed as a paracrine or autocrine factor that promotes neuronal precursor mitosis during development of the olfactory system (Chen et al., 2004b). NOS expression has been reported in cultures of neuronal precursors obtained from mouse SVZ (Wang et al., 1999). NO promotes neurogenesis in the SVZ and the hippocampus of adult animals in response to ischemia (Zhang et al., 2001; Lu et al., 2003; Chen et al., 2004a; Keynes and Garthwaite, 2004). Furthermore, in ischemic dentate gyrus of adult mice, iNOS expression and activity are necessary for the stimulation of the proliferation of neuronal precursors (Zhu et al., 2003). In primary cultures of olfactory precursors, NO donors promote proliferation and iNOS inhibitors promote differentiation, inhibiting cell proliferation (Sulz, unpublished).

It has been suggested that factors that regulate the sGS activity may have a role during neuronal development (Weller and Klein, 1992; Giuili et al., 1994), both in proliferation and survival of olfactory neurons (Chen et al., 2003), in axonic outgrowth and in synaptic plasticity in vitro (Hess et al., 1993). On the other hand, NO seems to stimulate proliferation of olfactory neuronal precursor cells in a cGMPindependent fashion (Sulz, unpublished).

The experimental studies reviewed here indicate a dual role for $\mathrm{NO}$ in embryonic and adult neurogenesis (Fig 2), as NO synthesized by nNOS appears to reduce 
neurogenesis acting as an antiproliferative molecule (Bredt and Snyder, 1994; Roskams et al., 1994; Peunova et al., 2001; Packer et al., 2003; Holmqvist et al., 2004; Matarredona et al., 2004; Moreno-Lopez et al., 2004), whereas the production of NO by iNOS and eNOS seems to stimulate neurogenesis (Zhang et al., 2001; Lu et al., 2003; Zhu et al., 2003; Chen et al., 2004a; Keynes and Garthwaite, 2004; Reif et al., 2004).

As in the GD and SVZ after focal ischemia, in the regenerating olfactory epithelium neuronal precursor proliferation is stimulated by NO likely produced by iNOS (Sulz, unpublished), suggesting that the NO proliferative effect observed in this tissue is functionally similar to those observed in other regenerating systems, where cell death is a signal that triggers iNOS expression in the damaged tissue.

Accordingly, neuronal death in the olfactory epithelium would be followed by the generation of NO, which would stimulate proliferation of basal cells, the neuronal precursors. A plausible signal linking cell death and NO generation is the leukaemia inhibitory factor (LIF). When the olfactory neurons are damaged and die, they transiently generate LIF. At the same time, the LIF receptor (gp130/LIFR) is transiently expressed in basal cells, axons of apoptotic neurons and infiltrated macrophages (Satoh and Yoshida, 1997; Nan et al., 2001; Getchell et al., 2002; Bauer et al., 2003). Macrophage depletion at this time severely impairs proliferation of neuronal precursors (Borders et al., 2006). LIF induces basal cell proliferation in vitro (Satoh and Yoshida, 1997; Bauer et al., 2003; Kim et al., 2005), therefore it is a primary feedback signal that increases neuronal precursor proliferation in the event of sensory neuron death, acting via the JAK/STAT3 pathway (Moon et al., 2002). This action may involve NO, because in the immune system LIF induces iNOS expression through the JAK/STAT pathway (Kleinert et al., 2003). In this model, NO would act downstream of LIF promoting neuronal precursor proliferation after olfactory sensory neurons die (Fig 3).

\section{CONCLUSION}

The evidence reviewed herein suggests a proliferative role for $\mathrm{NO}$ in olfactory epithelium regeneration. The mechanisms involved in the induction iNOS expression or of the NO proliferative effects are still unknown.
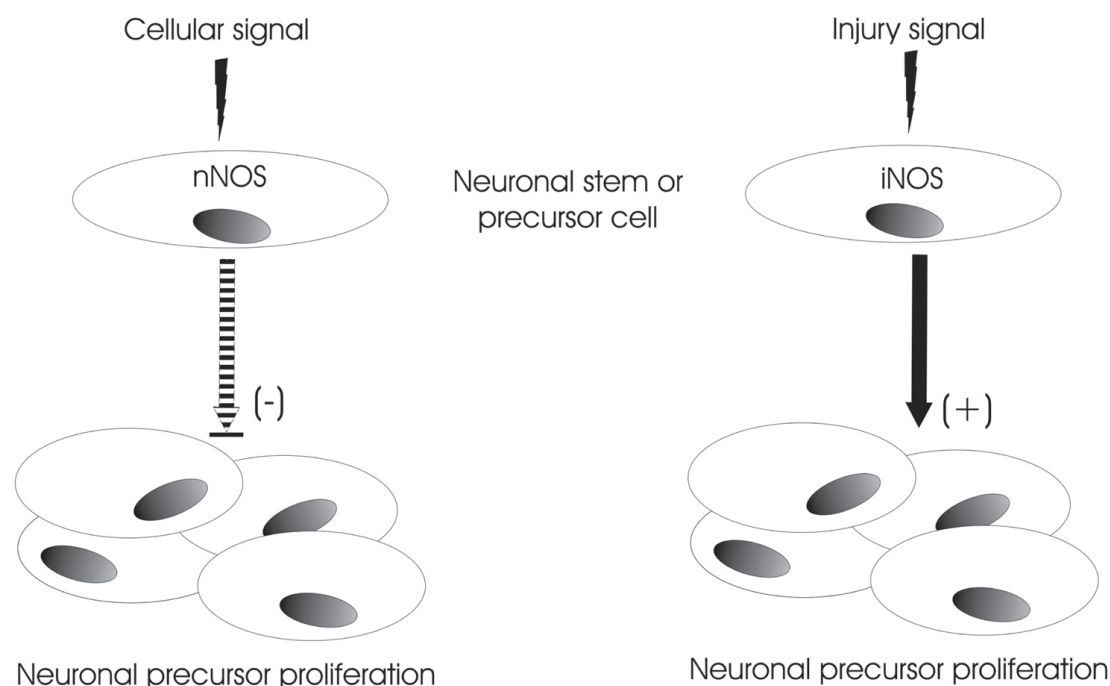

Figure 2: Neuronal precursors or stem cells respond in different forms to particular environmental signals. These cells express either nNOS in response to a normal neurogenic signal, inhibiting cell proliferation, or iNOS in response to an injury signal, stimulating cell proliferation. 


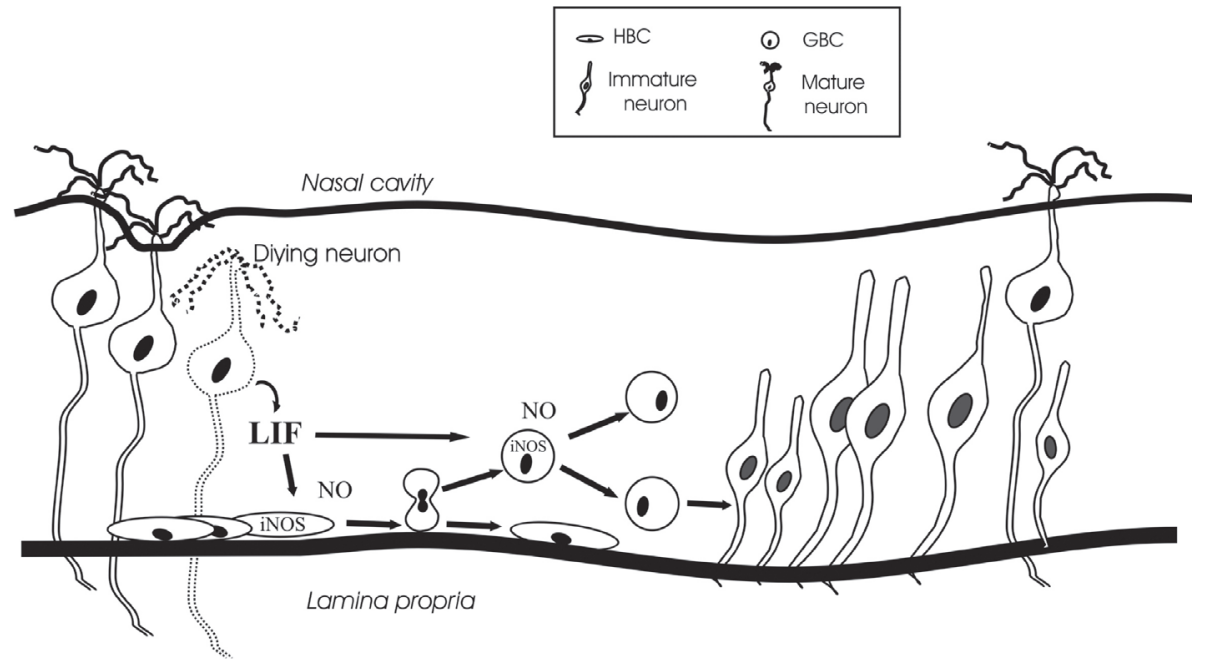

Figure 3: Model of proliferation induced by injury in the olfactory epithelium. A dying neuron produces LIF, which induces the expression of iNOS in horizontal basal cells (HBC) or global basal cells (GBC). The NO generated by iNOS stimulates the proliferation of neuronal precursors.

\section{ACKNOWLEDGMENTS}

Grants MIDEPLAN ICM P99-031-F, ICM P05-001-F and CONICYT Programa Bicentenario en Ciencia y Tecnología, ACT 45 .

\section{REFERENCES}

ALTMAN J, DAS GD (1965) Autoradiographic and histological evidence of postnatal hippocampal neurogenesis in rats. J Comp Neurol 124: 319-335

ASTIC L, SAUCIER D (2001) Neuronal plasticity and regeneration in the olfactory system of mammals: morphological and functional recovery following olfactory bulb deafferentation. Cell Mol Life Sci 58: 538-545

BACIGALUPO J, JOHNSON EC, VERGARA C, LISMAN JE (1991) Light-dependent channels from excised patches of Limulus ventral photoreceptors are opened by cGMP. Proc Natl Acad Sci U S A 88: 7938-7942

BAKALYAR HA, REED RR (1990) Identification of a specialized adenylyl cyclase that may mediate odorant detection. Science 250: 1403-1406

BARBER RD, JAWORSKY DE, YAU KW, RONNETT GV (2000) Isolation and in vitro differentiation of conditionally immortalized murine olfactory receptor neurons. J Neurosci 20: 3695-3704

BAUER S, RASIKA S, HAN J, MAUDUIT C, RACCURT $M$, MOREL G, JOURDAN F, BENAHMED M, MOYSE E, PATTERSON P (2003) Leukemia inhibitory factor is a key signal for injury-induced neurogenesis in the adult mouse olfactory epithelium. $J$ Neurosci 23: 1792-1803

BORDERS AS, GETCHELL ML, ETSCHEIDT J, COHEN DA, GETCHELL TV (2006) Macrophage depletion in murine olfactory epithelium leads to decrease neurogenesis. In Association for Chemoreception Sciences, pp. 115, Sarasota, FL, USA

BOSS BD, PETERSON GM, COWAN WM (1985) On the number of neurons in the dentate gyrus of the rat. Brain Res 338: 144-150

BRANDT I, BRITTEBO EB, FEIL VJ, BAKKE JE (1990) Irreversible binding and toxicity of the herbicide dichlobenil (2,6-dichlorobenzonitrile) in the olfactory mucosa of mice. Toxicol Appl Pharmacol 103: 491-501

BREDT DS, SNYDER SH (1994) Transient nitric oxide synthase neurons in embryonic cerebral cortical plate, sensory ganglia, and olfactory epithelium. Neuron 13: 301-313

BUCK L, AXEL R (1991) A novel multigene family may encode odorant receptors: a molecular basis for odor recognition. Cell 65: 175-187

BUCKLAND ME, CUNNINGHAM AM (1998) Alterations in the neurotrophic factors BDNF, GDNF and CNTF in the regenerating olfactory system. Ann N Y Acad Sci 855: $260-265$

CAGGIANO M, KAUER JS, HUNTER DD (1994) Globose basal cells are neuronal progenitors in the olfactory epithelium: a lineage analysis using a replication-incompetent retrovirus. Neuron 13: 339-352

CALOF AL, CHIKARAISHI DM (1989) Analysis of neurogenesis in a mammalian neuroepithelium: proliferation and differentiation of an olfactory neuron precursor in vitro. Neuron 3: 115-127

CAMARA CG, HARDING JW (1984) Thymidine incorporation in the olfactory epithelium of mice: early exponential response induced by olfactory neurectomy. Brain Res 308: 63-68

CAMERON HA, MCKAY R (1998) Stem cells and neurogenesis in the adult brain. Curr Opin Neurobiol 8: 677-680

CANCALON P (1982) Degeneration and regeneration of olfactory cells induced by $\mathrm{ZnSO} 4$ and other chemicals. Tissue Cell 14: 717-733

CARR VM, FARBMAN AI (1992) Ablation of the olfactory bulb up-regulates the rate of neurogenesis and induces precocious cell death in olfactory epithelium. Exp Neurol 115: 55-59 
CARTER LA, MACDONALD JL, ROSKAMS AJ (2004) Olfactory horizontal basal cells demonstrate a conserved multipotent progenitor phenotype. J Neurosci 24: 5670-5683

CHEN J, LI Y, ZHANG R, KATAKOWSKI M, GAUTAM SC, XU Y, LU M, ZHANG Z, CHOPP M (2004a) Combination therapy of stroke in rats with a nitric oxide donor and human bone marrow stromal cells enhances angiogenesis and neurogenesis. Brain Res 1005: 21-28

CHEN J, TU Y, MOON C, MATARAZZO V, PALMER AM, RONNETT GV (2004b) The localization of neuronal nitric oxide synthase may influence its role in neuronal precursor proliferation and synaptic maintenance. Dev Biol 269: 165-182

CHEN J, ZHANG ZG, LI Y, WANG Y, WANG L, JIANG $\mathrm{H}$, ZHANG C, LU M, KATAKOWSKI M, FELDKAMP CS, CHOPP M (2003) Statins induce angiogenesis, neurogenesis, and synaptogenesis after stroke. Ann Neurol 53: 743-751

CUNNINGHAM AM, MANIS PB, REED RR, RONNETT GV (1999) Olfactory receptor neurons exist as distinct subclasses of immature and mature cells in primary culture. Neuroscience 93: 1301-1312

DAWSON TM, BREDT DS, FOTUHI M, HWANG PM, SNYDER SH (1991) Nitric oxide synthase and neuronal NADPH diaphorase are identical in brain and peripheral tissues. Proc Natl Acad Sci U S A 88: 7797 7801

DAWSON TM, DAWSON VL, SNYDER SH (1993) Nitric oxide as a mediator of neurotoxicity. NIDA Res Monogr 136: 258-271; discussion 271-253

DAWSON TM, DAWSON VL, SNYDER SH (1994) Molecular mechanisms of nitric oxide actions in the brain. Ann N Y Acad Sci 738: 76-85

DELALEU JC, SICARD G (1995) Physiological and histological recovery of the olfactory mucosa of the frog after a dichlobenil injection. Chem Senses 20: 433-440

EDELMAN GM, GALLY JA (1992) Nitric oxide: linking space and time in the brain. Proc Natl Acad Sci U S A 89: 11651-11652

ERIKSSON PS, PERFILIEVA E, BJORK-ERIKSSON T, ALBORN AM, NORDBORG C, PETERSON DA, GAGE FH (1998) Neurogenesis in the adult human hippocampus. Nat Med 4: 1313-1317

FARBMAN AI (1990) Olfactory neurogenesis: genetic or environmental controls? Trends Neurosci 13: $362-365$

FARBMAN AI, BUCHHOLZ JA (1996) Transforming growth factor-alpha and other growth factors stimulate cell division in olfactory epithelium in vitro. $\mathrm{J}$ Neurobiol 30: 267-280

FERON F, MACKAY-SIM A, ANDRIEU JL, MATTHAEI KI, HOLLEY A, SICARD G (1999a) Stress induces neurogenesis in non-neuronal cell cultures of adult olfactory epithelium. Neuroscience 88: 571-583

FERON F, VINCENT A, MACKAY-SIM A (1999b) Dopamine promotes differentiation of olfactory neuron in vitro. Brain Res 845: 252-259

FIRESTEIN BL, BREDT DS (1998) Regulation of sensory neuron precursor proliferation by cyclic GMPdependent protein kinase. J Neurochem 71: 1846-1853

FIRESTEIN S, ZUFALL F, SHEPHERD GM (1991) Single odor-sensitive channels in olfactory receptor neurons are also gated by cyclic nucleotides. J Neurosci 11: $3565-3572$

GAGE FH (2000) Mammalian neural stem cells. Science 287: $1433-1438$

GARTHWAITE J (1991) Glutamate, nitric oxide and cellcell signalling in the nervous system. Trends Neurosci 14: $60-67$
GARTHWAITE J, BOULTON CL (1995) Nitric oxide signaling in the central nervous system. Annu Rev Physiol 57: 683-706

GENTER MB, DEAMER NJ, CAO Y, LEVI PE (1994) Effects of P450 inhibition and induction on the olfactory toxicity of beta,beta'-iminodipropionitrile (IDPN) in the rat. J Biochem Toxicol 9: 31-39

GETCHELL TV, SHAH DS, PARTIN JV, SUBHEDAR NK, GETCHELL ML (2002) Leukemia inhibitory factor mRNA expression is upregulated in macrophages and olfactory receptor neurons after target ablation. J Neurosci Res 67: 246-254

GIUILI G, LUZI A, POYARD M, GUELLAEN G (1994) Expression of mouse brain soluble guanylyl cyclase and NO synthase during ontogeny. Brain Res Dev Brain Res 81: 269-283

GORDON MK, MUMM JS, DAVIS RA, HOLCOMB JD, CALOF AL (1995) Dynamics of MASH1 expression in vitro and in vivo suggest a non-stem cell site of MASH1 action in the olfactory receptor neuron lineage. Mol Cell Neurosci 6: 363-379

GOULD E, MCEWEN BS, TANAPAT P, GALEA LA, FUCHS E (1997) Neurogenesis in the dentate gyrus of the adult tree shrew is regulated by psychosocial stress and NMDA receptor activation. J Neurosci 17: 24922498

GOULD E, TANAPAT P (1999) Stress and hippocampal neurogenesis. Biol Psychiatry 46: 1472-1479

GOULDING EH, NGAI J, KRAMER RH, COLICOS S, AXEL R, SIEGELBAUM SA, CHESS A (1992) Molecular cloning and single-channel properties of the cyclic nucleotide-gated channel from catfish olfactory neurons. Neuron 8: 45-58

GRAZIADEI PP (1973) Cell dynamics in the olfactory mucosa. Tissue Cell 5: 113-131

GRAZIADEI PP, MONTI GRAZIADEI AG (1983) Regeneration in the olfactory system of vertebrates. Am J Otolaryngol 4: 228-233

GRAZIADEI PP, MONTI GRAZIADEI GA (1979) Neurogenesis and neuron regeneration in the olfactory system of mammals. I. Morphological aspects of differentiation and structural organization of the olfactory sensory neurons. J Neurocytol 8: 1-18

GRAZIADEI PP, MONTI GRAZIADEI GA (1980) Neurogenesis and neuron regeneration in the olfactory system of mammals. III. Deafferentation and reinnervation of the olfactory bulb following section of the fila olfactoria in rat. J Neurocytol 9: 145-162

GUDI T, HONG GK, VAANDRAGER AB, LOHMANN SM, PILZ RB (1999) Nitric oxide and cGMP regulate gene expression in neuronal and glial cells by activating type II cGMP-dependent protein kinase. Faseb J 13: 2143-2152

HARDING J, GRAZIADEI PP, MONTI GRAZIADEI GA, MARGOLIS FL (1977) Denervation in the primary olfactory pathway of mice. IV. Biochemical and morphological evidence for neuronal replacement following nerve section. Brain Res 132: 11-28

HAYNES LW, KAY AR, YAU KW (1986) Single cyclic GMP-activated channel activity in excised patches of rod outer segment membrane. Nature 321: 66-70

HEMPSTEAD JL, MORGAN JI (1983) Monoclonal antibodies to the rat olfactory sustentacular cell. Brain Res 288: 289-295

HESS SD, DOROSHENKO PA, AUGUSTINE GJ (1993) A functional role for GTP-binding proteins in synaptic vesicle cycling. Science 259: 1169-1172

HINDS JW, HINDS PL, MCNELLY NA (1984) An autoradiographic study of the mouse olfactory epithelium: evidence for long-lived receptors. Anat Rec 210: $375-383$ 
HOLBROOK EH, SZUMOWSKI KE, SCHWOB JE (1995) An immunochemical, ultrastructural, and developmental characterization of the horizontal basal cells of rat olfactory epithelium. J Comp Neurol 363: 129-146

HOLMQVIST B, ELLINGSEN B, FORSELL J, ZHDANOVA I, ALM P (2004) The early ontogeny of neuronal nitric oxide synthase systems in the zebrafish. J Exp Biol 207: 923-935

HURTT ME, THOMAS DA, WORKING PK, MONTICELLO TM, MORGAN KT (1988) Degeneration and regeneration of the olfactory epithelium following inhalation exposure to methyl bromide: pathology, cell kinetics, and olfactory function. Toxicol Appl Pharmacol 94: 311-328

ILLING N, BOOLAY S, SIWOSKI JS, CASPER D, LUCERO MT, ROSKAMS AJ (2002) Conditionally immortalized clonal cell lines from the mouse olfactory placode differentiate into olfactory receptor neurons. Mol Cell Neurosci 20: 225-243

JONES DT, REED RR (1989) Golf: an olfactory neuron specific-G protein involved in odorant signal transduction. Science 244: 790-795

KEILHOFF G, SEIDEL B, NOACK H, TISCHMEYER W, STANEK D, WOLF G (1996) Patterns of nitric oxide synthase at the messenger RNA and protein levels during early rat brain development. Neuroscience 75 : 1193-1201

KEYNES RG, GARTHWAITE J (2004) Nitric oxide and its role in ischaemic brain injury. Curr Mol Med 4: 179-191

KIM EJ, SIMPSON PJ, PARK DJ, LIU BQ, RONNETT GV, MOON C (2005) Leukemia inhibitory factor is a proliferative factor for olfactory sensory neurons. Neuroreport 16: 25-28

KLEINERT H, SCHWARZ PM, FORSTERMANN U (2003) Regulation of the expression of inducible nitric oxide synthase. Biol Chem 384: 1343-1364

KUHN HG, WINKLER J, KEMPERMANN G, THAL LJ, GAGE FH (1997) Epidermal growth factor and fibroblast growth factor-2 have different effects on neural progenitors in the adult rat brain. J Neurosci 17: 5820-5829

KUZIN B, REGULSKI M, STASIV Y, SCHEINKER V, TULLY T, ENIKOLOPOV G (2000) Nitric oxide interacts with the retinoblastoma pathway to control eye development in Drosophila. Curr Biol 10: 459-462

KUZIN B, ROBERTS I, PEUNOVA N, ENIKOLOPOV G (1996) Nitric oxide regulates cell proliferation during Drosophila development. Cell 87: 639-649

LEUNG CT, REED RR (2006) Horizontal basal cells are multipotent neuronal progenitos in olfactory epithelium. In Association for Chemoreception Sciences, pp. 115, Sarasota, FL, USA

LU D, MAHMOOD A, ZHANG R, COPP M (2003) Upregulation of neurogenesis and reduction in functional deficits following administration of DEtA/ NONOate, a nitric oxide donor, after traumatic brain injury in rats. J Neurosurg 99: 351-361

MACKAY-SIM A, KITTEL P (1991) Cell dynamics in the adult mouse olfactory epithelium: a quantitative autoradiographic study. J Neurosci 11: 979-984

MAHALIK TJ (1996) Apparent apoptotic cell death in the olfactory epithelium of adult rodents: death occurs at different developmental stages. J Comp Neurol 372: 457-464

MAHANTHAPPA NK, SCHWARTING GA (1993) Peptide growth factor control of olfactory neurogenesis and neuron survival in vitro: roles of EGF and TGF-beta s. Neuron 10: 293-305
MATARREDONA ER, MURILLO-CARRETERO M, MORENO-LOPEZ B, ESTRADA C (2004) Nitric oxide synthesis inhibition increases proliferation of neural precursors isolated from the postnatal mouse subventricular zone. Brain Res 995: 274-284

MENCO BP, CUNNINGHAM AM, QASBA P, LEVY N, REED RR (1997) Putative odour receptors localize in cilia of olfactory receptor cells in rat and mouse: a freeze-substitution ultrastructural study. J Neurocytol 26: 691-706

MIN YG, RHEE CS, CHOO MJ, SONG HK, HONG SC (1994) Histopathologic changes in the olfactory epithelium in mice after exposure to sulfur dioxide. Acta Otolaryngol 114: 447-452

MIZE RR, LO F (2000) Nitric oxide, impulse activity, and neurotrophins in visual system development(1). Brain Res 886: 15-32

MONCADA S, PALMER RM, HIGGS EA (1991) Nitric oxide: physiology, pathophysiology, and pharmacology. Pharmacol Rev 43: 109-142

MOON C, YOO JY, MATARAZZO V, SUNG YK, KIM EJ, RONNETT GV (2002) Leukemia inhibitory factor inhibits neuronal terminal differentiation through STAT3 activation. Proc Natl Acad Sci U S A 99: 90159020

MORALES B, BACIGALUPO J (1996) Chemical reception in vertebrate olfaction: evidence for multiple transduction pathways. Biol Res 29: 333-341

MORALES B, MADRID R, BACIGALUPO J (1997) Calcium mediates the activation of the inhibitory current induced by odorants in toad olfactory receptor neurons. FEBS Lett 402: 259-264

MORALES B, UGARTE G, LABARCA P, BACIGALUPO $J$ (1994) Inhibitory $K+$ current activated by odorants in toad olfactory neurons. Proc Biol Sci 257: 235-242

MORENO-LÓPEZ B, ROMERO-GRIMALDI C, NOVAL JA, MURILLO-CARRETERO M, MATARREDONA ER, ESTRADA C (2004) Nitric oxide is a physiological inhibitor of neurogenesis in the adult mouse subventricular zone and olfactory bulb. J Neurosci 24: 85-95

MORO MA, CÁRDENAS A, HURTADO O, LEZA JC, LIZASOAIN I (2004) Role of nitric oxide after brain ischaemia. Cell Calcium 36: 265-275

MOULTON DG (1974) Dynamics of cell populations in the olfactory epithelium. Ann N Y Acad Sci 237: 52-61

NAN B, GETCHELL ML, PARTIN JV, GETCHELL TV (2001) Leukemia inhibitory factor, interleukin-6, and their receptors are expressed transiently in the olfactory mucosa after target ablation. J Comp Neurol 435: 60-77

NATHAN C (1992) Nitric oxide as a secretory product of mammalian cells. Faseb J 6: 3051-3064

NEWMAN MP, FERON F, MACKAY-SIM A (2000) Growth factor regulation of neurogenesis in adult olfactory epithelium. Neuroscience 99: 343-350

OBREGON E, PUNZON MC, GONZÁLEZ-NICOLAS J, FERNÁNDEZ-CRUZ E, FRESNO M, MUÑOZFERNÁNDEZ MA (1997) Induction of adhesion/ differentiation of human neuroblastoma cells by tumour necrosis factor-alpha requires the expression of an inducible nitric oxide synthase. Eur J Neurosci 9: 1184-1193

OKANO HJ, PFAFF DW, GIBBS RB (1996) Expression of EGFR-, p75NGFR-, and PSTAIR (cdc2)-like immunoreactivity by proliferating cells in the adult rat hippocampal formation and forebrain. Dev Neurosci 18: 199-209

PACKER MA, STASIV Y, BENRAISS A, CHMIELNICKI E, GRINBERG A, WESTPHAL H, GOLDMAN SA, ENIKOLOPOV G (2003) Nitric oxide negatively 
regulates mammalian adult neurogenesis. Proc Natl Acad Sci U S A 100: 9566-9571

PAYS L, SCHWARTING G (2000) Gal-NCAM is a differentially expressed marker for mature sensory neurons in the rat olfactory system. J Neurobiol 43: 173-185

PEUNOVA N, ENIKOLOPOV G (1993) Amplification of calcium-induced gene transcription by nitric oxide in neuronal cells. Nature 364: 450-453

PEUNOVA N, ENIKOLOPOV G (1995) Nitric oxide triggers a switch to growth arrest during differentiation of neuronal cells. Nature 375: 68-73

PEUNOVA N, SCHEINKER V, CLINE H, ENIKOLOPOV G (2001) Nitric oxide is an essential negative regulator of cell proliferation in Xenopus brain. J Neurosci 21: 8809-8818

PINEDA J, KOGAN JH, AGHAJANIAN GK (1996) Nitric oxide and carbon monoxide activate locus coeruleus neurons through a cGMP-dependent protein kinase: involvement of a nonselective cationic channel. J Neurosci 16: 1389-1399

PIXLEY SK, DANGORIA NS, ODOMS KK, HASTINGS L (1998) Effects of insulin-like growth factor 1 on olfactory neurogenesis in vivo and in vitro. Ann $\mathrm{N} \mathrm{Y}$ Acad Sci 855: 244-247

PLENDL J, STIERSTORFER B, SINOWATZ F (1999) Growth factors and their receptors in the olfactory system. Anat Histol Embryol 28: 73-79

REIF A, SCHMITT A, FRITZEN S, CHOURBAJI S, BARTSCH C, URANI A, WYCISLO M, MOSSNER R, SOMMER C, GASS P, LESCH KP (2004) Differential effect of endothelial nitric oxide synthase (NOS-III) on the regulation of adult neurogenesis and behaviour. Eur J Neurosci 20: 885-895

RHEIN LD, CAGAN RH (1980) Biochemical studies of olfaction: isolation, characterization, and odorant binding activity of cilia from rainbow trout olfactory rosettes. Proc Natl Acad Sci U S A 77: 4412-4416

ROSKAMS AJ, BREDT DS, DAWSON TM, RONNETT GV (1994) Nitric oxide mediates the formation of synaptic connections in developing and regenerating olfactory receptor neurons. Neuron 13: 289-299

SANTACANA M, UTTENTHAL LO, BENTURA ML, FERNÁNDEZ AP, SERRANO J, MARTÍNEZ DE VELASCO J, ALONSO D, MARTÍNEZ-MURILLO R, RODRIGO J (1998) Expression of neuronal nitric oxide synthase during embryonic development of the rat cerebral cortex. Brain Res Dev Brain Res 111: 205-222

SATOH M, YOSHIDA T (1997) Promotion of neurogenesis in mouse olfactory neuronal progenitor cells by leukemia inhibitory factor in vitro. Neurosci Lett 225: 165-168

SATOH M, YOSHIDA T (2000) Expression of neural properties in olfactory cytokeratin-positive basal cell line. Brain Res Dev Brain Res 121: 219-222

SAUCIER D, ASTIC L (1995) Morpho-functional alterations in the olfactory system of rainbow trout (Oncorhynchus mykiss) and possible acclimation in response to long-lasting exposure to low copper levels. Comp. Biochem. Physiol. 112A: 273-284

SCHILD D, RESTREPO D (1998) Transduction mechanisms in vertebrate olfactory receptor cells. Physiol Rev 78: 429-466

SCHMACHTENBERG O, BICKER G, BACIGALUPO J (2001) NADPH diaphorase is developmentally regulated in rat olfactory epithelium. Neuroreport 12: 1039-1043

SCHULTZ EW (1960) Repair of the olfactory mucosa with special reference to regeneration of olfactory cells (sensory neurons). Am J Pathol 37: 1-19
SCHWARTZ LEVEY M, CHIKARAISHI DM, KAUER JS (1991) Characterization of potential precursor populations in the mouse olfactory epithelium using immunocytochemistry and autoradiography. J Neurosci 11: 3556-3564

SCHWOB JE, SZUMOWSKI KE, STASKY AA (1992) Olfactory sensory neurons are trophically dependent on the olfactory bulb for their prolonged survival. J Neurosci 12: 3896-3919

SCHWOB JE, YOUNGENTOB SL, MEZZA RC (1995) Reconstitution of the rat olfactory epithelium after methyl bromide-induced lesion. J Comp Neurol 359: $15-37$

SCOTT SP, HARRISON RW, WEBER IT, TANAKA JC (1996) Predicted ligand interactions of 3'5'-cyclic nucleotide-gated channel binding sites: comparison of retina and olfactory binding site models. Protein Eng 9: 333-344

SEROOGY KB, GALL CM, LEE DC, KORNBLUM HI (1995) Proliferative zones of postnatal rat brain express epidermal growth factor receptor mRNA. Brain Res 670: 157-164

SIMPSON PJ, WANG E, MOON C, MATARAZZO V, COHEN DR, LIEBL DJ, RONNETT GV (2003) Neurotrophin-3 signaling maintains maturational homeostasis between neuronal populations in the olfactory epithelium. Mol Cell Neurosci 24: 858-874

SMITH CG (1951) Regeneration of sensory olfactory epithelium and nerves in adult frogs. Anat Rec 109: 661-671

SNYDER SH (1992) Nitric oxide and neurons. Curr Opin Neurobiol 2: 323-327

STAMLER JS (1994) Redox signaling: nitrosylation and related target interactions of nitric oxide. Cell 78: 931936

STAMLER JS, JIA L, EU JP, MCMAHON TJ, DEMCHENKO IT, BONAVENTURA J, GERNERT K, PIANTADOSI CA (1997a) Blood flow regulation by Snitrosohemoglobin in the physiological oxygen gradient. Science 276: 2034-2037

STAMLER JS, TOONE EJ, LIPTON SA, SUCHER NJ (1997b) (S)NO signals: translocation, regulation, and a consensus motif. Neuron 18: 691-696

TAO Y, BLACK IB, DICICCO-BLOOM E (1996) Neurogenesis in neonatal rat brain is regulated by peripheral injection of basic fibroblast growth factor (bFGF) J Comp Neurol 376: 653-663

VAN WAGENEN S, REHDER V (2001) Regulation of neuronal growth cone filopodia by nitric oxide depends on soluble guanylyl cyclase. J Neurobiol 46: 206-219

VERGE VM, XU Z, XU XJ, WIESENFELD-HALLIN Z, HOKFELT T (1992) Marked increase in nitric oxide synthase mRNA in rat dorsal root ganglia after peripheral axotomy: in situ hybridization and functional studies. Proc Natl Acad Sci U S A 89: 11617-11621

VERHAAGEN J, OESTREICHER AB, GRILLO M, KHEW-GOODALL YS, GISPEN WH, MARGOLIS FL (1990) Neuroplasticity in the olfactory system: differential effects of central and peripheral lesions of the primary olfactory pathway on the expression of B50/GAP43 and the olfactory marker protein. J Neurosci Res 26: 31-44

WANG T, FITZGERALD TJ, HAREGEWOIN A (1999) Differential expression of nitric oxide synthases in EGF-responsive mouse neural precursor cells. Cell Tissue Res 296: 489-497

WEISS S, VAN DER KOOY D (1998) CNS stem cells where's the biology (a.k.a. beef)? J Neurobiol 36: 307 314 
WELLER JL, KLEIN DC (1992) The pineal adrenergic-cyclic GMP response develops two weeks after the adrenergic--cyclic AMP response. Brain Res Dev Brain Res 68: 144-147

WESTERMAN RA, VON BAUMGARTEN R (1964) Regeneration of olfactory paths in carp (Cyprinus carpio L.) Experientia 20: 519-520

ZHANG R, ZHANG L, ZHANG Z, WANG Y, LU M, LAPOINTE M, CHOPP M (2001) A nitric oxide donor induces neurogenesis and reduces functional deficits after stroke in rats. Ann Neurol 50: 602-611

ZHU DY, LIU SH, SUN HS, LU YM (2003) Expression of inducible nitric oxide synthase after focal cerebral ischemia stimulates neurogenesis in the adult rodent dentate gyrus. J Neurosci 23: 223-229

ZORUMSKI CF, IZUMI Y (1993) Nitric oxide and hippocampal synaptic plasticity. Biochem Pharmacol 46: 777-785 
